\title{
Research on the Impact of Green Credit on the Financial Performance of Commercial Banks
}

\begin{abstract}
Xingbang Yin*
School of Economics, Anhui University of Finance and Economics, Bengbu 233000, Anhui province, China. E-mail: 648743527@qq.com

Abstract: From the perspective of green credit, this paper makes a theoretical analysis of the impact of green credit on the financial performance of commercial banks. Based on the panel data of 15 commercial banks from 2012 to 2018 , this paper makes an empirical analysis on the impact mechanism is empirically analyzed. The results show that in the short-term, green credit has a negative impact on the financial performance of commercial banks, and the adverse impact faced by small and medium-sized commercial banks is significantly higher than that of large commercial banks, showing a heterogeneous effect. This also reveals the effect of commercial banks in implementing green credit in commercial banks and reasons for low initiative and enthusiasm. In view of this, it puts forward specific policy recommendations for different types of commercial banks, and believes that they should effectively promote green credit business in terms of differentiated policy guidelines and increasing the training of interdisciplinary talents.
\end{abstract}

Keywords: Green Credit; Financial Performance; Heterogeneous Influence

\section{Introduction}

My country's green financial policies and concepts based on green credit are being widely promoted and implemented nationwide, with the goal of achieving sustainable economic and social development. In my country's financial system, the assets of banking financial institutions accounted for $91.54 \%$ of the total financial assets, and the it business accounted for $49.50 \%$ of the assets of the banking industry ${ }^{[1]}$. In the process of allocating financial resource, green credit has played a core role in promoting green finance.

Green credit means that commercial banks actively guide the flow of funds through credit means, reduce loans to industries and projects with "high pollution, and overcapacity", while increasing credit support for low-emission and low-polluting industries and projects, and gradually changing the "extensive" business "Business model to promote the development of local green economy. From the data of 21 major banks in my country at the end of June 2019, it can be seen that although the total amount of green credit has reached more than 10 trillion yuan, it is showing a situation of high growth rate and low proportion", with an annual growth rate of $12.8 \%$, And the proportion is only maintained at about $6.5 \%{ }^{[2]}$. Green credit has a certain impact on the competitiveness of commercial banks and environmental risk management. Commercial banks need to combine their own resources and positioning to make a tween benefits and costs. Therefore, studying the impact of commercial banks on their financial performance after implementing green credit policies will facilitate different types of commercial banks to recognize the situation, better implement green credit policies, and promote the sound development of green credit.

Copyright (C) 2021 Xingbang Yin

doi: $10.18686 /$ fm.v6i1.3267

This is an open-access article distributed under the terms of the Creative Commons Attribution Non-Commercial License

(http://creativecommons.org/licenses/by-nc/4.0/), which permits unrestricted non-commercial use, distribution, and reproduction in any medium,

provided the original work is properly cited. 


\section{References}

In recent years, scholars have conducted a lot of theoretical and empirical analysis on the issue of green credit affecting the financial performance of commercial banks. Wang Xiaoluo proposed that environmental governance investment will increase with improvement of bank assets quality ${ }^{[1]}$; Lazzatoni et al. believe that the development of green finance will have a significant impact on the financial performance of commercial banks ${ }^{[2]}$; Campiglio proposed that commercial banks should avoid the status quo of its own operations may have adverse effects, and may refuse to lend to low-carbon businesses and environmentally friendly companies ${ }^{[3]}$; Zhang Changjiang and others discussed the relationship between green credit and commercial bank performance based on the intermediary effect of green reputation, and believed that despite the implementation of green credit policies, Commercial banks will still cause adverse effects, but green credit lending behavior will produce green reputation effects, which can play a positive role in improving the financial performance of commercial banks ${ }^{[4]}$; Yan Tingfeng et al. proceeded from the perspective of systems, technology, and institutions, It is believed that the short-term effect of green credit on the financial performance of commercial banks is weak, but the long-term effect is more obvious, because the status quo of low income and high cost of green credit in the short term is difficult to improve quickly, which affects their operating profits, but helps to improve their profitability in the long run ${ }^{[5]}$.

\section{Variables and Data}

\subsection{Interpreted variables}

By the combing and analysis of empirical articles, it is found that domestic scholars have different opinions on which financial indicators should be used to measure the financial performance of commercial banks. If we ignore the risks related to financial leverage, you can choose the return on equity (ROE); if you consider from the perspective of comprehensively measuring the profitability of all aspects of commercial banks' assets, you can choose). This article starts from the perspective of comprehensive income, so the latter is selected.

\subsection{Core explanatory variables}

Regarding how to evaluate the extent of a commercial bank's green credit business, some domestic scholars advocate using green credit ratio (that is, the proportion of green credit balance to the total loan amount) as a measure, but the time and depth of green credit business development is limited, resulting in green credit The ratio is low and it is difficult to make objective evaluation. Therefore, this paper uses green credit balance (GL) as the core explanatory variable, and takes the natural logarithm to reduce data fluctuations. The greater the value, the larger the scale of green credit and the more green funds invested by commercial banks ${ }^{[6]}$.

\subsection{Other control variables}

(1) Bank characteristic variables. Considering all kinds of factors, the control variables to measure the financial performance of commercial banks can generally use indicators representing the adequacy of loan loss reserves of commercial banks, such as provision coverage ratio (BBFGL), and the non-performing loan ratio (BLDKL) and the capital adequacy ratio (CAR) of the ability to withstand risks can also be analyzed with the aid of the commercial bank asset scale (SIZE) indicator. Generally speaking, commercial banks with larger total assets are more capable of using economies of scale to reduce costs and increase profits. In empirical analysis, logarithmic transformations of corresponding variables are used to reduce data fluctuations.

(2) Macroeconomic variables. Indicators to measure the level of macroeconomic development, including indicators related to economic development and the overall level of prices. This article chooses gross domestic product (GDP), broad money supply (M2) and consumer price index (CPI) to measure the impact of changes in the external economy on commercial banks from a macro perspective. In summary, the final model variables selected in this paper are shown in Table 1. 
Table 1. Model variables

\begin{tabular}{|l|l|l|}
\hline Variable Category & Variable Name & Symbol \\
\hline Explained Variable & Return on total assets & ROA \\
\hline Explanatory Variables & Green credit balance & GL \\
\hline \multirow{5}{*}{ Control Variable } & Provision coverage & BBFGL \\
\cline { 2 - 3 } & Bad debt ratio & BLDKL \\
\cline { 2 - 3 } & Capital adequacy ratio & CAR \\
\cline { 2 - 3 } & Bank size & SIZE \\
\cline { 2 - 3 } & Gross domestic product & GDP \\
\cline { 2 - 3 } & Consumer Price Index & CPI \\
\cline { 2 - 3 } & Currency supply & M2 \\
\hline
\end{tabular}

\section{Empirical Analysis}

\section{1 Model Setting}

The Husman test is used. The null hypothesis of the test is that the individual influence in the random effects model is not related to the explanatory variables. According to the final test results, the samples can reject the null hypothesis. Therefore, when establishing the static panel model, the random effects model is abandoned and the fixed effects model is selected. The benchmark model is:

$R O A_{i t}=\partial_{i}+\beta_{1} G L_{i t}+\beta \chi_{i t}+\varepsilon_{i t}$

(Model 1)

Divide the sample into three groups, and perform stepwise regression on each sample group. Only the core explanatory variables are added to Model 2, and the micro characteristics and macroeconomic variables of banks are added to Model 3 and Model 4.

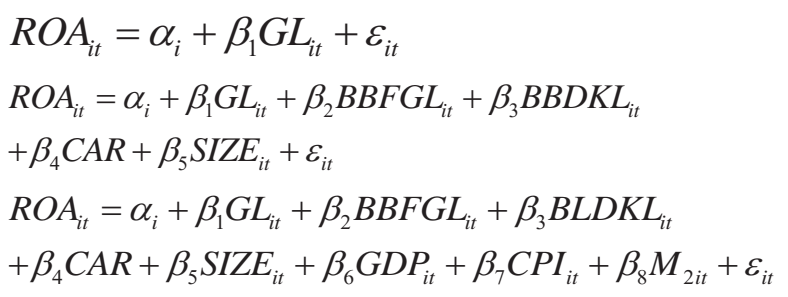

Among them, $\mathrm{i}$ and $\mathrm{t}$ represent each bank and year respectively, $\mathrm{ROA}_{\mathrm{it}}$ represents the financial performance of bank $\mathrm{i}$ in year $\mathrm{t}, \mathrm{GL}_{\mathrm{it}}$ represents the green credit balance of bank $\mathrm{i}$ in year $\mathrm{t}, \varepsilon_{\mathrm{it}}$ represents the random disturbance item, and $\chi_{i t}$ represents the control variable. According to the previous relevant literature, the internal influencing factors $\mathrm{BBFGL}_{\mathrm{it}}, \mathrm{BBDKL}_{\mathrm{it}}, \mathrm{CAR}_{\mathrm{it}}$ and $\mathrm{SIZE}_{\mathrm{it}}$ representing the characteristics of the bank, as well as the external factors $\mathrm{GDP}_{\mathrm{it}}$, $\mathrm{CPI}_{\mathrm{it}}$ and $\mathrm{M} 2_{\mathrm{it}}$ representing the macroeconomics, were selected and included in Model 2, Model 3, and Model 4, respectively. Estimate in.

\subsection{Regression Analysis}

All samples, samples of large commercial banks, and samples of small and medium commercial banks were included in the control variables according to the model for stepwise regression. The regression results of the model are shown in Table 2, and Table 3.

Table 2 shows the results of stepwise regression of control variables included in all samples. In the model regression result 1 , the coefficient of the green credit balance is -0.1522 , which has passed the significance test at the level of $1 \%$, indicating that the green credit balance has a negative impact on the profitability of commercial banks. This can be explained as the fact that my country has not implemented a green financial policy based on green credit for a long time. It was only after the introduction of the Green Credit Guidelines in 2012 that green credit has received the attention of 
commercial banks. Therefore, on the one hand, the balance of green credit accounts for a limited proportion of the bank's total assets, and it is difficult to have a large impact on its profitability; on the other hand, the cost of pre-assessment, process tracking and other links in the green credit distribution process of commercial banks is relatively low. And generally use preferential interest rate is relatively high, so it will reduce the return on total assets of commercial banks to a certain extent. In model regression results 2 and model regression results 3, the green credit balance coefficient is positive, but it fails the significance test. The coefficients of the provision coverage ratio are 0.1613 and 0.1382 , respectively, which pass the significance at the $1 \%$ confidence level. The test shows that the increase in the provision coverage ratio promotes the profitability of banks; the coefficients of the non-performing loan ratio are -0.1502 and -0.1398 respectively, which are significantly negative at the $1 \%$ confidence level, indicating that the increase in the non-performing loan ratio will weaken commercial banks Profitability. For example, the non-performing loan ratio shown in the model regression result 2 will increases by 1 percentage point, the return on total assets will decrease by about 0.15 percentage points; the macro control variables have a negative impact on the return on total assets, but it is not significant.

Table 2. Regression results of all samples

\begin{tabular}{|c|c|c|c|}
\hline Variable & Model 1 & Model2 & Model3 \\
\hline LNGL & $\begin{array}{l}-0.1522 * * * \\
(0.0000)\end{array}$ & $\begin{array}{l}0.0081 \\
(0.4608)\end{array}$ & $\begin{array}{l}0.0064 \\
(0.6922)\end{array}$ \\
\hline LNBBFGL & & $\begin{array}{l}0.1613 * * * \\
(0.0000)\end{array}$ & $\begin{array}{l}0.1382 * * * \\
(0.0005)\end{array}$ \\
\hline LNBLDKL & & $\begin{array}{l}-0.1502 * * * \\
(0.0000)\end{array}$ & $\begin{array}{l}-0.1398^{* * *} \\
(0.0000)\end{array}$ \\
\hline LNCAR & & $\begin{array}{l}-0.1724^{* *} \\
(0.0249)\end{array}$ & $\begin{array}{l}-0.0199 \\
(0.8519)\end{array}$ \\
\hline LNSIZE & & $\begin{array}{l}-0.3907 * * * \\
(0.0000)\end{array}$ & $\begin{array}{l}-0.1559 * \\
(0.0798)\end{array}$ \\
\hline LNGDP & & & $\begin{array}{l}-0.0330 \\
(0.9052)\end{array}$ \\
\hline LNCPI & & & $\begin{array}{l}-2.7243^{* *} \\
(0.0289)\end{array}$ \\
\hline LNM2 & & & $\begin{array}{l}-0.3878 * \\
(0.0576) \\
\end{array}$ \\
\hline Constant term & $\begin{array}{l}1.95 * * * \\
(0.0000)\end{array}$ & & $\begin{array}{l}16.02 * * \\
(0.0113)\end{array}$ \\
\hline $\bar{R}^{2}$ & 0.82 & 0.94 & 0.95 \\
\hline
\end{tabular}

Table 3. Regression results of large commercial banks

\begin{tabular}{|l|l|l|l|}
\hline Variable & Model4 & Model4 & Model6 \\
\hline \multirow{2}{*}{ LNGL } & $-0.1338^{* * *}$ & $\begin{array}{l}0.0537^{* * *} \\
(0.0084)\end{array}$ & $\begin{array}{l}0.0403^{* *} \\
(0.0397)\end{array}$ \\
\hline \multirow{2}{*}{ LNBBFGL } & & $\begin{array}{l}0.0680 \\
(0.3574)\end{array}$ & $\begin{array}{l}-0.010 \\
(0.8844)\end{array}$ \\
\hline
\end{tabular}




\begin{tabular}{|l|l|l|l|}
\hline LNBLDKL & & $\begin{array}{l}0.0098 \\
(0.8830)\end{array}$ & $\begin{array}{l}-0.0102 \\
(0.8890)\end{array}$ \\
\hline LNCAR & & $\begin{array}{l}-0.2057 \\
(0.2184)\end{array}$ & $\begin{array}{l}-0.3727 * * \\
(0.0461)\end{array}$ \\
\hline LNSIZE & & $\begin{array}{l}-0.6634^{* * *} \\
(0.0000)\end{array}$ & $\begin{array}{l}-1.1903 * * * \\
(0.0042)\end{array}$ \\
\hline LNGDP & & & $\begin{array}{l}0.6011 \\
(0.1228)\end{array}$ \\
\hline LNCPI & & & $\begin{array}{l}-1.2764 \\
(0.3669)\end{array}$ \\
\hline LNM2 & & & $\begin{array}{l}-0.0151 \\
(0.9762)\end{array}$ \\
\hline Constant term & $2.23 * * *$ & $2.64 * * *$ & $\begin{array}{l}8.56 \\
(0.2317)\end{array}$ \\
\hline $\bar{R}^{2}$ & $(0.0000)$ & $(0.0000)$ & 0.97 \\
\hline
\end{tabular}

\section{Conclusions}

The introduction of green credit will have a negative impact on the financial performance of commercial banks to a certain extent, and shows heterogeneity among different types of commercial banks. The main reasons for the above results are as follows: First, in the short term, the proportion of green credit issued by commercial banks to the total loan balance is low, and the time for implementing green credit policies is relatively short, and the system and regulations are not sound, so it is difficult to show green credit. The second is that large commercial banks accelerate the training of green finance-related talents and reduce the marginal cost of green credit. At the same time, due to the information and supervision in place, they can recover the green credits they have invested in the early stage to a certain extent and obtain the success of income. The rate is higher than that of small and medium commercial banks ${ }^{[7]}$.

\section{References}

1. Wang X. Environmental governance investment and bank asset quality: analysis based on the perspective of green credit. Financial Forum 2016; (11): 12 - 19.

2. Simone Lazzaroni, Davide Ravelli, Stefano Protti, et al. Photochemical synthesis: Using light to build C-C bonds under mild conditions. Comptes Rendus Chimie 2017; 20(3): 261 - 271.

3. Emanuele Campiglio. Beyond carbon pricing: The role of banking and monetary policy in financing the transition to a low-carbon economy. Ecological Economics 2016; (6): 121.

4. Zhang C, Zhang Y. Can green credit improve the performance of commercial banks: Intermediary effect based on green reputation. Financial Development Research 2019; (7): 70 - 76.

5. Yan T, Xu X, Ren S. Green Credit and Bank Financial Performance: Based on the Perspective of Institutions, Technology and Institutions. Jiangxi Social Sciences 2019; 39(7): 63 - 72.

6. Zhang L, Lian Y. Green credit, bank heterogeneity and bank financial performance. Financial Supervision Research 2019; (2): $43-61$.

7. He L, Wu C, Zhong Z, et al. Green credit, internal and external policies and the competitiveness of commercial banks: an empirical study based on 9 listed commercial banks. Financial Economics Research 2018; 33(1): $91-103$. 